\title{
胆汁りン脂質に関する研究
}

\author{
大阪大学医学部木谷内科（主任教授 木行威毁）
}

北村次男

\section{STUDIES ON PHOSPHOLIPIDES IN BILE}

\author{
Tugio Kitamura \\ The Second Department of Internal Medicine, Osaka University Medical School
}

(Prof.: Takeo Kitani)

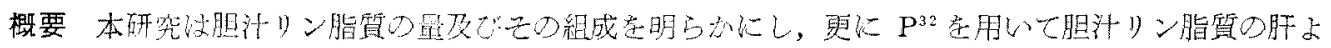

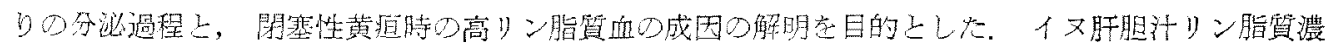

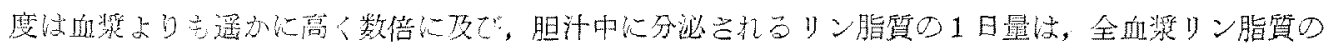

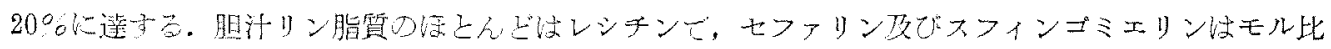

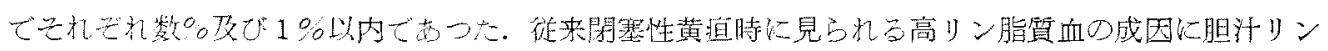

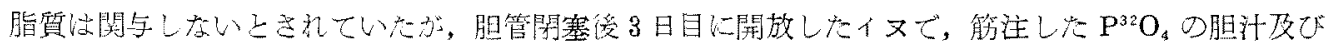

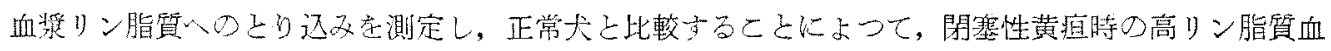

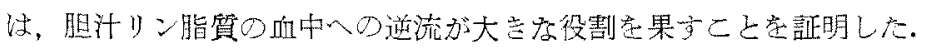

\section{I 緒 言}

最近胆汁リン脂覧は胆汁中のコレステロールを 溶解させる成分として重視されている1)。 John一 ston and Nakayama は, 大豆りン脂質とりシの 胆裂胆汁を服用させると，胆汁中にリン脂質と胆 汁酸塭の排泄が増加寸ることを見出し，これによ つてコレステロール胆石を溶解せしめる作用のあ ることを報告している2)。しかし胆汁リン脂貿の 值は，その測定方法がまだ不完全であり報告者に 上り異なるため，個々の報告に大きな変動がある

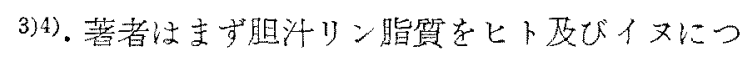
いて, Zilversmit らの方法5)より定量し, シ リカゲルのカラムクロマトグラフィーにより質的 な湓討をも行なつた。更に $\mathrm{P}^{32} \mathrm{O}_{4}$ を用いて胆汁 リン脂質生成機棈を䀒におけるリン脂質代謝の面 より究明した。

さて，閉塞性黄㾝により著明な高りン脂唕血 の抗こることは，古くから知られている事寒であ る。 Balfour は, 閉塞性黄疸患者に $\mathrm{P}^{32} \mathrm{O}_{4}$ を注
射し，血清リン脂質へのとり込みを測定して開塞 性黄㾝患者においても的存の䯩りン脂質血に稀鄱 されることなく, 正常の血清リン脂質値を示す者 と同じように血清りン脂筫の高い比放射能が得ら れるという事奉から，䀒におけるりン脂質合成 の增加が高りン脂質血の発生に関与するものと推 測している6. しかしこの上うな血清リン脂質の 比放射能測定のみでは，胆汁中のリン脂暂方血中 に逆流することを否定し得ない，そこで著者は $\mathrm{P}^{32} \mathrm{O}_{4}$ を用いて盘清並びに胆汁りン脂質へのと り込双を測定し，閉塞性黄但時の高リン脂筫血の 成因をしらへてて胆汁リン脂質の役慧を明らかにし 得たので報告する。

\section{II 実験方法}

A）リン唱質の抽出, 定量及びカラムクロマト グラフィー

旰，血清及び血漿りン䁕筫の抽出は，クロロ ホルム (以下クロと略す) 対メタ)ール (以下み 夕と略す) $2 ： 1 に よ り$ 還流冷却器付のコルベン 
中で $60^{\circ} \mathrm{C} 20$ 分間搔出を 3 回反復した。胆汁りン脂 質の抽出は，旦汁 1管を》口対メ夕 2：1030容 により，上記コルベン中で $60^{\circ} \mathrm{C} 1$ 㭙間抽出在行な

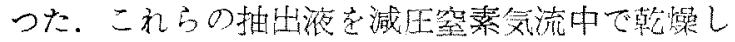
た復, フロて平抽出し，再抽出豁媒の半容のメ夕

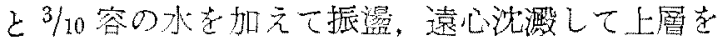
挨て，Folch の方法》に準じて同比率混合溶㖼の 上層を加元て更に2 度水洗した，水洗得婊面に 残る上層に詨しては少量のメ夕を加えて均一化し た。

脂貿リンはは過塩菜酸て酸化分解した彷 FiskeSubbarow の方汢泣より無機りンとして測定 し, エタノールアミン・セファリンは Axelrod

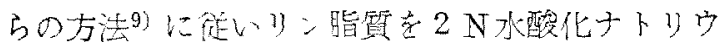
ムでアルカリ水鳞した镜，エ夕ノールアミンをD NP化して比色定量した、スフィンゴミエリンも

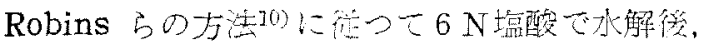
スフインコシン孝DNP化して比色測定した。放

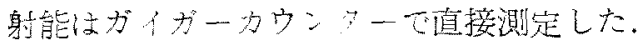

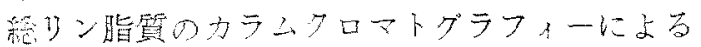

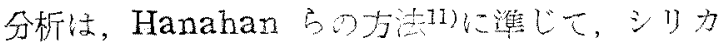

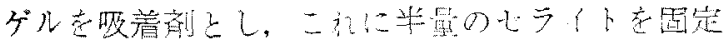

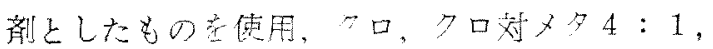
クロ対メ夕3：2，又夕て逐次溶出した。リン脂

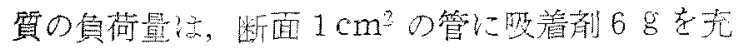

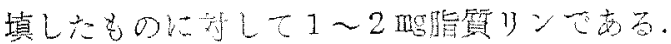

B) 臨床笑䮖

1) 㫜汁》方采取

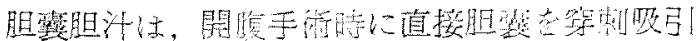

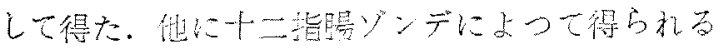
B胆汁使用した。

2) P $\mathrm{P}^{32}$ の血清りン脂兵への上り远みの测定

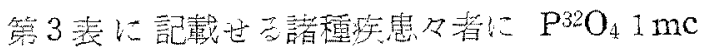
を筋注し，42甠間设に埰血し上記の方法に上り， 脂筫りンとをの放射能索則定した。

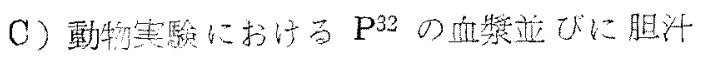
リン脂筫人のとり迟加の測起

イヌをナオペンタールナトリウムて磿要して開

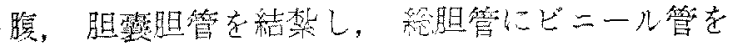

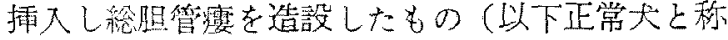
す)，更にこのビニール管学結禁し度下に埋没して 閉塞怪黄疸を起こきせ，術後3 日目に埋没したビ ニール管を取り出し結慗を開放し総胆管瘦を造設 したもの（以下閉塞後開放犬と称す），別に胆雯胆

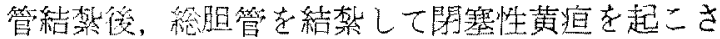

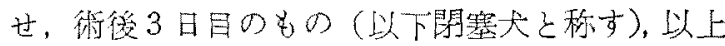
3 種の1双に $\mathrm{P}^{32} \mathrm{O}_{4} 0.05 \sim 0.5 \mathrm{mc} / \mathrm{kg}$ 女筋注し,

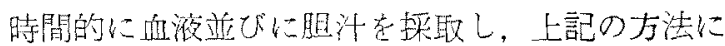
より脂質りンとその放射能を測定した。

\section{III 実験成績}

A) 胆汁リン脂䫓に閣する基整的事項

1）胆汁りン脂質の安定性

イメの胆汁を採取した㢺 $37^{\circ} \mathrm{C} に$ 保方，1時盟ご とに3時間後まで，てのエステル脂酸立立びに脂質 リン在測定し，採敢直後のものと此輘したが両者 ともに見るべき差晎がなかつた。

2) 胆汁リン脂質の量

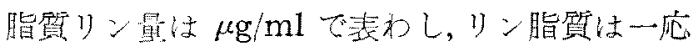
すバでレシチンさみなして，脂質リンの值に25

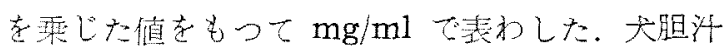

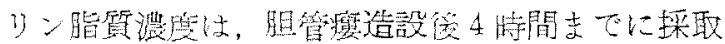
せる斗ので、正常犬で平均 $12.2 \mathrm{mg} / \mathrm{ml}$ ，閉塞後

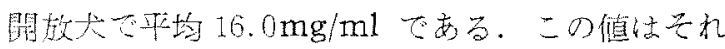

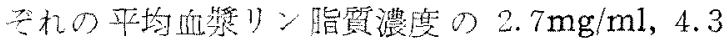

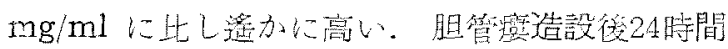

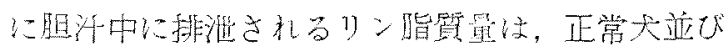

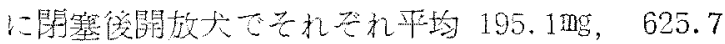

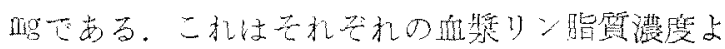

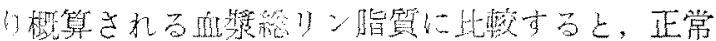

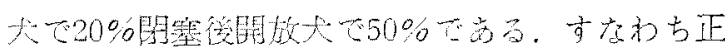

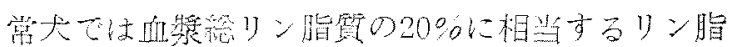

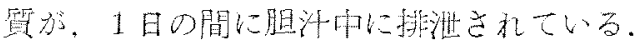

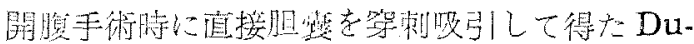

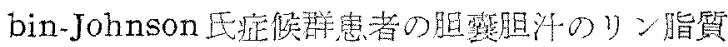
灙度は， $16.9 \mathrm{mg} / \mathrm{ml}$ という高漂度であつた。旰 硬䘫㭧者に早朝然腹時十二指腸ゾンデを行なって 得たB胆汁では，平均 $2.0 \mathrm{mg} / \mathrm{ml}$ で市つた（籍 1 恙). 


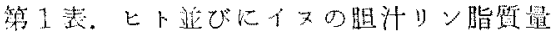

\begin{tabular}{|c|c|c|c|c|c|}
\hline \multirow{2}{*}{\multicolumn{3}{|c|}{ 胆汁の種類 }} & \multicolumn{2}{|c|}{ 胆汁リン脂傎 } & \multirow{3}{*}{ 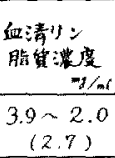 } \\
\hline & & & \multirow{2}{*}{$\begin{array}{c}\text { 震 } \\
\begin{array}{c}\text { 度 } \\
26.2 \sim 4 / \mathrm{mt} \\
(12.2)\end{array} \\
\end{array}$} & \multirow{2}{*}{ 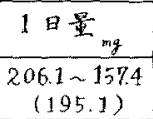 } & \\
\hline \multirow{2}{*}{ 犬 } & \multirow{2}{*}{ 肝胆汁 } & 正常 & & & \\
\hline & & 间察往 & $\begin{array}{c}189-112 \\
(16.0)\end{array}$ & $\begin{array}{c}954.2-322.6 \\
(625.7)\end{array}$ & $\begin{array}{c}5.2 \sim 3.4 \\
(4.3)\end{array}$ \\
\hline \multirow[b]{2}{*}{ ト } & 胆紫胆 & 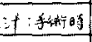 & 16.9 & - & \multirow[b]{2}{*}{ (1.9) } \\
\hline & \multicolumn{2}{|c|}{ 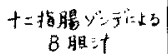 } & $2.4 \sim 1.4$ & $\ldots$ & \\
\hline
\end{tabular}

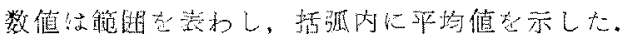

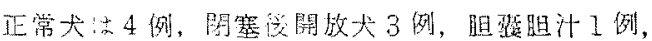
$\mathrm{B}$ 䶙计 3 例。

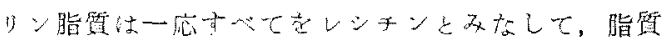
リンの值に25を乘じ値をるつて琵っした。

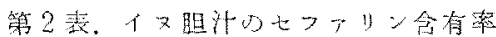

\begin{tabular}{|c|c|c|c|c|c|}
\hline 試料 & セファリン & 方法 & 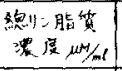 & 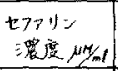 & 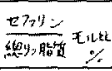 \\
\hline 1 & 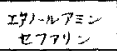 & $\begin{array}{l}A \times E ! r o d \\
D . N P \text {. }= \pm\end{array}$ & 54.6 & 0.15 & 0.27 \\
\hline 2 & 2 & 3 & 52.2 & 0.55 & 1.05 \\
\hline 3 & $"$ & , & 32.0 & 0.47 & 1.48 \\
\hline 4 & 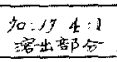 & 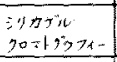 & - & - & 3.24 \\
\hline 5 & ", & " & - & - & 6.06 \\
\hline
\end{tabular}

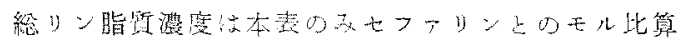

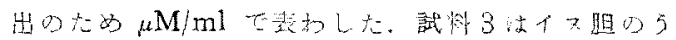

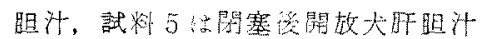

3) 胆汁リン脂贀の分画

DNP化法によつて測定したエ夕ノールアミン ・セファリンの総リン脂質中で占める割谷は，モ ル比で0.27\%〜1.48\%であり，シリカゲルクロマ トグラフィ一分析法によれ㥙，ク口封メ夕4：1 で溶出するセファリン分雨の占的る割合は $3 \sim 6$ \%であつた(籍2 表)。

DN P化法によつて測定したスフィンコミエリ ンの総リン脂質中で占める割合も，1\%以下の少 量に過ぎなかた。

シリカゲルクロマトグラフィーでは, クロ刘メ 夕4：1 溶出するセファリンの低い山西る が，7ロ封邓夕 $3: 2$ 分画の前部分に法脂望りン

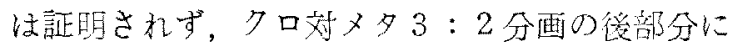
おいてほとんど單一な溶出明線を示すとシチンの

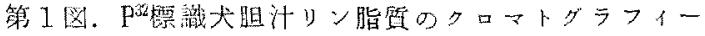

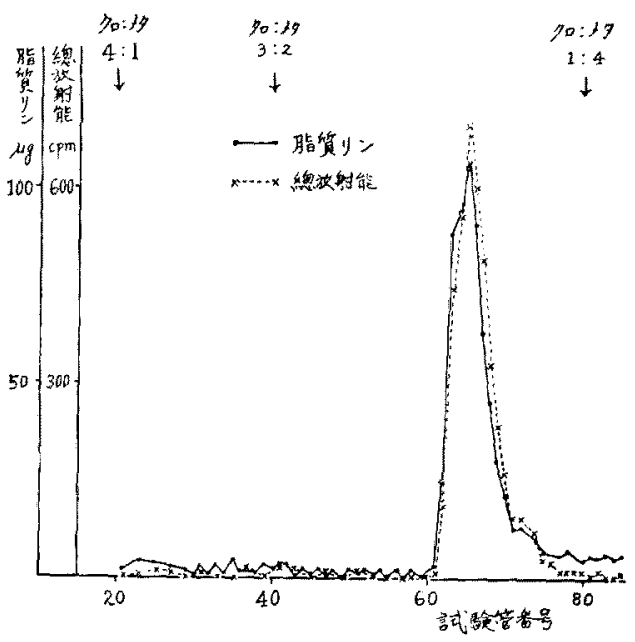

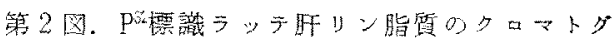
$\Rightarrow>1-$

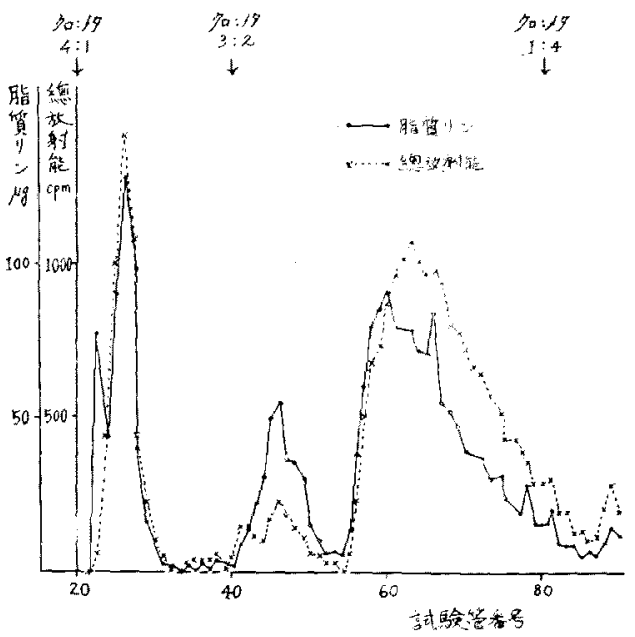

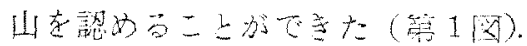

4） $\mathrm{P}^{32}$ 標識りン脂貿のクロマトグラフィー分 析

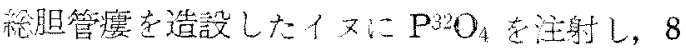
時閒後に得られな胆㳆からりン脂質を抽出し、ク ロマトグラフィーで分析して脂質りンる放射能の 溶出伹楾をしらハた。放射解はリンの溶出曲線に 相当してフロ刘タタ3：2 分画の佼战分に汪とん ぞ它全に集中して山をつくる(筹1四)、䈆2四は 效比の目的古多つて, in vivoて $\mathrm{P}^{32} \mathrm{O}_{4}$ にっって 


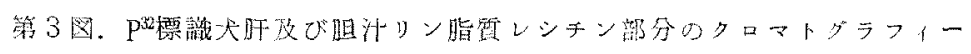

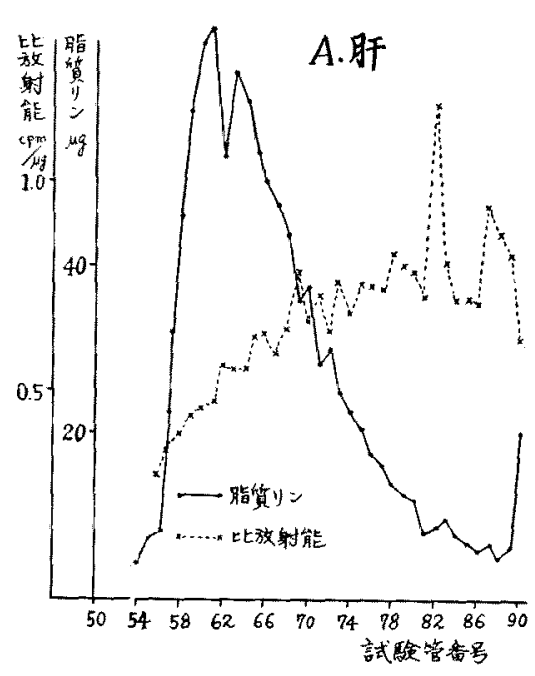

证識したラッテ全旰多ン脂質のクロマトグラフィ 一分析の結果を表わしたものである。この場合は 7 口対又夕 $4: 1$, 同 $3: 2$ の前部分画に强い放 射能存する少量成分が存在する沙。胆汁りン勗 質中にはこのような成分は諗められない，Marinetti の方法12)に基づいて, 2-pentanone-䄍酸

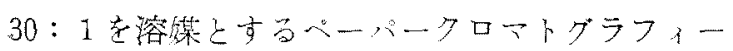
を行ない，オートラジオグラムによつて $P^{32}$ 在 祒出しな結果も同様で，放射能はレシチン部分に 汪とんど完全に局在する。

しかし胆汁リン脂質のシリカゲルクロマトグラ

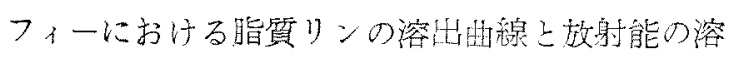
出曲線の山の間には僅吕子ずれが見られる。算 3 図B注比放射能の溶出分画による分布老図示した ものであるが，速く溶出する不飽和度の高い脂酸

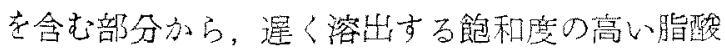
を含む部分に至るまて，比放射能注落明に増加す るのが認められる。こ扎虾りン䁕質の場合上一 致する傾向であつて，対比のた们第了図Aに イヌ肝リン脂貭の溶出出線乙比放射能曲線を示し た。

B）閉塞性黄渲時の高リン脂質血の成因につい $\tau$

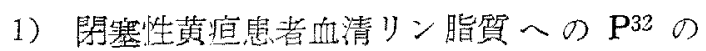

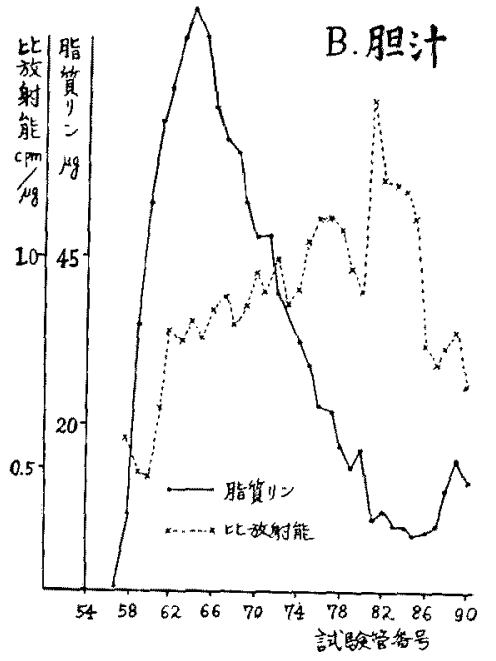

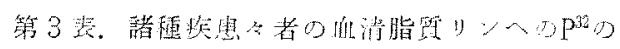
之记迅

\begin{tabular}{|c|c|c|c|c|c|}
\hline \multirow[b]{2}{*}{ 仱名 } & \multirow[b]{2}{*}{ 病名 } & \multirow[b]{2}{*}{ 黄疾指数 } & \multirow{2}{*}{\begin{tabular}{|c} 
脂筫りン \\
ug/ml
\end{tabular}} & \multicolumn{2}{|c|}{ 脂留りンの放射能 } \\
\hline & & & & 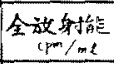 & 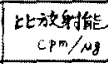 \\
\hline A.T. & 心臟弁凌症 & 8 & 36.0 & 2120 & 58.9 \\
\hline H.M. & 急性肝是 & 6 & 87.0 & 2030 & 23.3 \\
\hline U.T. & 肝硬变症 & 7 & 90.0 & 2090 & 23.2 \\
\hline K.T. & 肝硬交症 & 13 & 42.7 & 1940 & 45.3 \\
\hline T.M. & 用塞性黄㾝 & 39 & 94.5 & 3470 & 36.7 \\
\hline F. 0 . & 用塞性黄疾 & 225 & 288.0 & 10640 & 36.9 \\
\hline
\end{tabular}

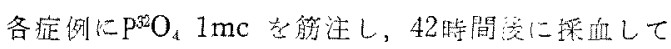
測定した放射能は筋注した放的能を $1 \times 10^{3} \mathrm{cpm} と$

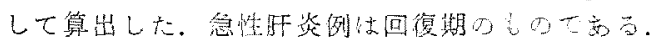

\section{上り込み}

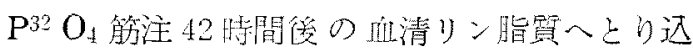
まれた放射能は，閏䈍性黄㡺患者ては黄疸のない ものに比して著明に增加しているが，比放射能で は雨者の間に差が見られない(第3言)。

2) 奏駼的胆管閉塞㒸秉血清リン脂質への $\mathrm{P}^{32}$ の上り远两

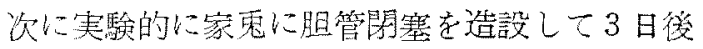
及び4日後に $\mathrm{P}^{32} \mathrm{O}_{4}$ 筋注して，㭙間を追つた 血清りン脂質中への $\mathrm{P}^{32}$ のとり迈みを見ると、 正常家鬼に比して胆管閉塞家雭では明らかなり

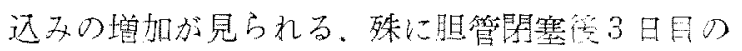




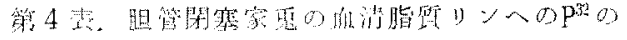
上设起办

\begin{tabular}{|c|c|c|c|c|c|c|c|c|c|c|}
\hline \multirow{3}{*}{ 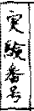 } & \multirow{3}{*}{ 它跡条件 } & \multicolumn{3}{|c|}{ 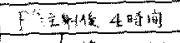 } & \multicolumn{3}{|c|}{ 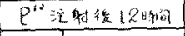 } & \multicolumn{3}{|c|}{ 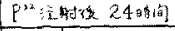 } \\
\hline & & \multirow{2}{*}{ 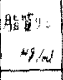 } & \multicolumn{2}{|c|}{ 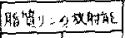 } & \multirow{2}{*}{ 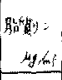 } & \multicolumn{2}{|c|}{ 影筧少，の奴的能 } & \multirow{2}{*}{ 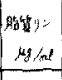 } & \multicolumn{2}{|c|}{ 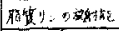 } \\
\hline & & & 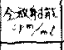 & 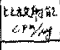 & & 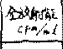 & 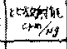 & & 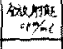 & 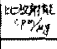 \\
\hline \multirow{2}{*}{ I } & 正常 & 360 & 90 & 2.5 & 36.0 & 440 & 123 & 517 & 1080 & 20.9 \\
\hline & 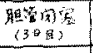 & 450 & 12020 & 21.5 & 630 & 2790 & 44.0 & 720 & 3880 & 53.9 \\
\hline & 正常 & 300 & 200 & 6.4 & 31.5 & 570 & 18.1 & 29.7 & 880 & 30.1 \\
\hline & 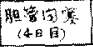 & 7.5 & 550 & $? .1$ & 71.1 & 1800 & 25.3 & 702 & 2740 & 39.0 \\
\hline
\end{tabular}

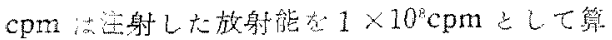
出した。

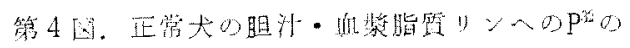
上设双

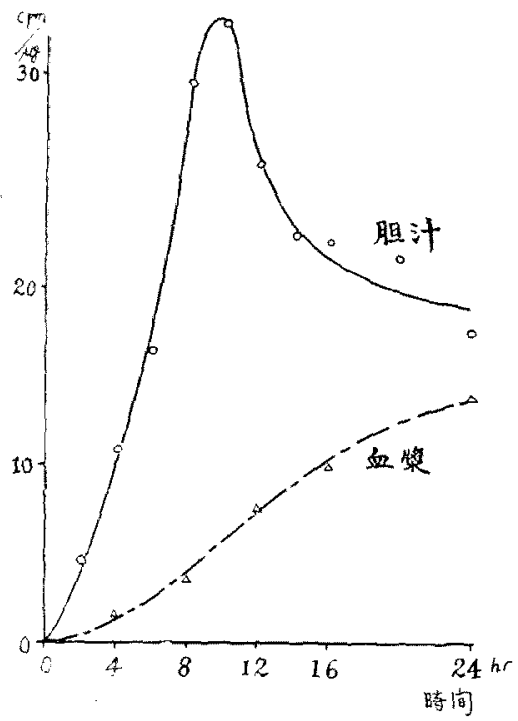

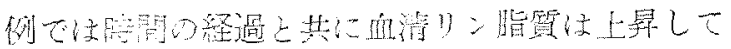

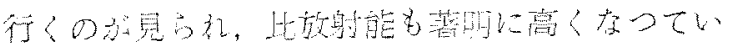
$3\left(\frac{10}{10} 4\right.$

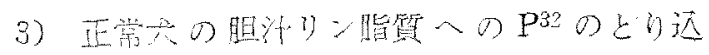
z.

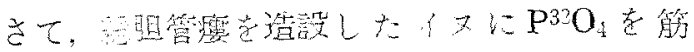

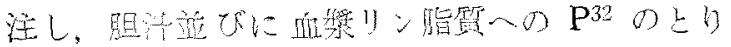

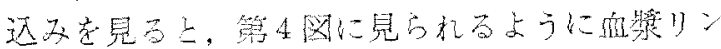

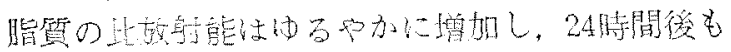

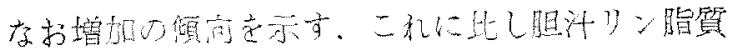

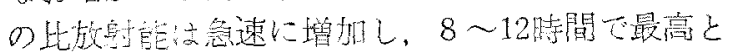

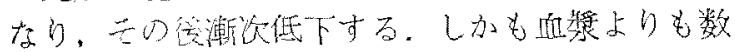

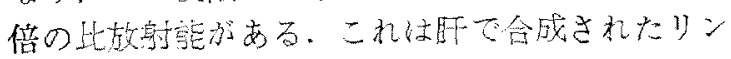

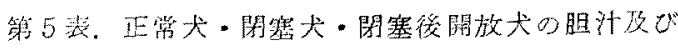

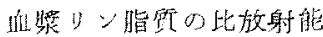

\begin{tabular}{|c|c|c|c|c|c|c|c|c|}
\hline & \multicolumn{4}{|c|}{ I } & \multicolumn{4}{|c|}{ 犬 } \\
\hline & \multicolumn{2}{|c|}{$I$} & \multicolumn{2}{|c|}{ II } & \multicolumn{2}{|c|}{ III } & \multicolumn{2}{|c|}{$\pi$} \\
\hline 時间 & 船汗 & 血徒是 & 月9:-1 & 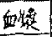 & 月盟涪 & 耻持 & AS江 & 血雙 \\
\hline 2 & 1.3 & 1.5 & 1.3 & & & & 0.4 & \\
\hline 4 & 6.1 & 0.9 & 10.0 & 0.3 & 11.0 & 1.7 & 6.2 & 0.7 \\
\hline 6 & 12.6 & 1.5 & 17.7 & & & & 14.6 & \\
\hline 8 & 31.2 & 3.9 & 24.0 & 36 & 29.5 & 3.5 & 21.7 & 3.3 \\
\hline 10 & 340 & 5.7 & 28.9 & & & & 29.6 & \\
\hline 12 & 320 & 7.4 & 28.2 & 8.9 & 259 & 77 & 28.6 & 6.3 \\
\hline 16 & & & 280 & 10.6 & 22.5 & 100 & 20.9 & 80 \\
\hline 18 & 30.5 & 13.8 & & & & & & \\
\hline 24 & 28.0 & 15.2 & 27.0 & 127 & 17.3 & 13.8 & {$[19,3$} & 12.0 \\
\hline
\end{tabular}

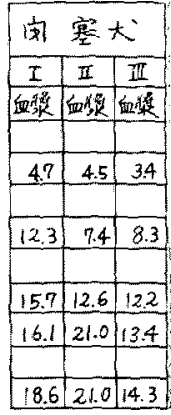

\begin{tabular}{|c|c|c|c|c|c|c|c|c|c|c|c|c|}
\hline & \multicolumn{6}{|c|}{ 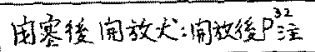 } & \multicolumn{6}{|c|}{ 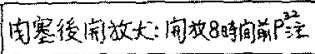 } \\
\hline & \multicolumn{2}{|c|}{$I$} & \multicolumn{2}{|c|}{ II } & \multicolumn{2}{|c|}{ III } & \multicolumn{2}{|c|}{$I$} & \multicolumn{2}{|c|}{ II } & \multicolumn{2}{|c|}{ III } \\
\hline 時自 & 照圷 & 血照 & 照汁 & 䅡量 & gest & 6 & 晅汗 & 如㧵 & 8 是汁 & 如猪 & 晅动 & 面慗 \\
\hline 2 & & & & & 7.8 & & & & & & & \\
\hline 4 & & & 287 & 1.1 & & 1.3 & & 4.3 & & 4.8 & & 2.3 \\
\hline 5 & 15.1 & 2.3 & & & & & & & & & & \\
\hline 6 & & & & & 233 & & & & & & & \\
\hline 8 & & & 31.3 & 3.6 & & 4.6 & & 8.5 & & 8.3 & & 6.7 \\
\hline 9 & & & & & & & 31.6 & & 38.1 & & 23.6 & \\
\hline 10 & 18.9 & 44 & & & 21.2 & & 31.9 & & 389 & & & \\
\hline 11 & & & & & & & & & & & 18.5 & \\
\hline 12 & & & 27.5 & 6.4 & & 6.8 & 26.0 & 126 & 30.2 & 10.4 & & 10.4 \\
\hline 14 & & & & & 215 & & & & & & 17.7 & \\
\hline 15 & 15.6 & 72 & & & & & & & & & & \\
\hline 16 & & & 258 & 82 & & 9.7 & 234 & 13.3 & 358 & 134 & & 120 \\
\hline 20 & 11.3 & 9.0 & & & 20.1 & & & & 33.3 & & 17.5 & \\
\hline 24 & & & 24.7 & 9.9 & & 11.0 & 22.1 & 157 & & 150 & & 132 \\
\hline 25 & 11.6 & 9.5 & & & & & & & & & & \\
\hline
\end{tabular}

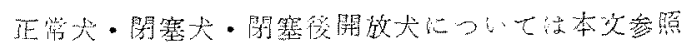

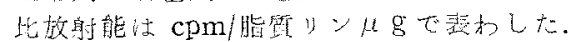

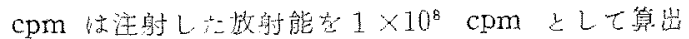

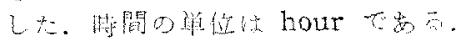

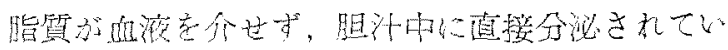

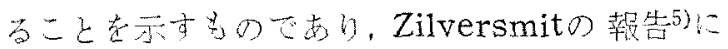
一玟するものでる。

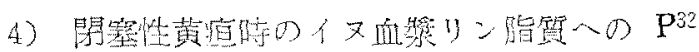
门上り西加

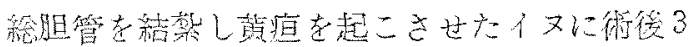

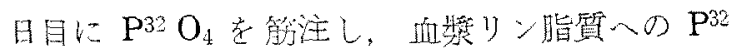

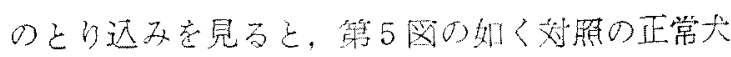

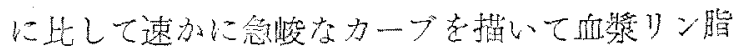

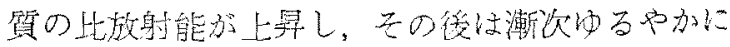

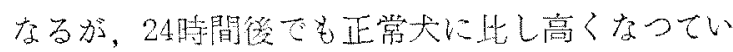
b.

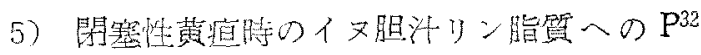




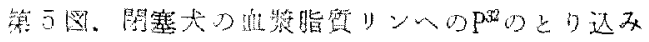

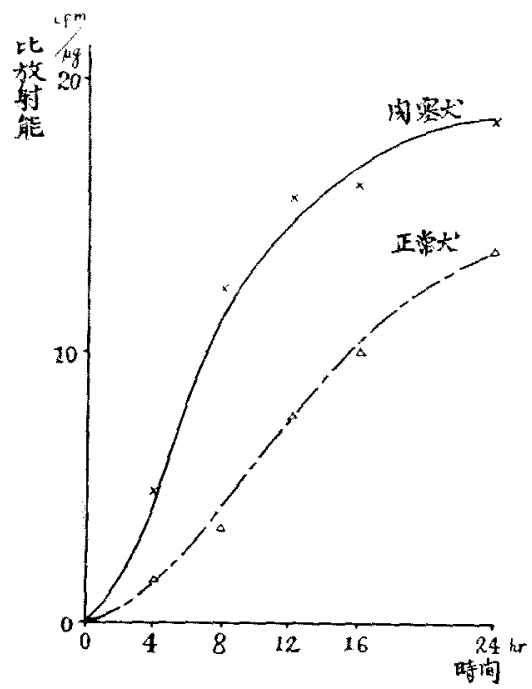

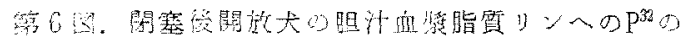
r i 记双

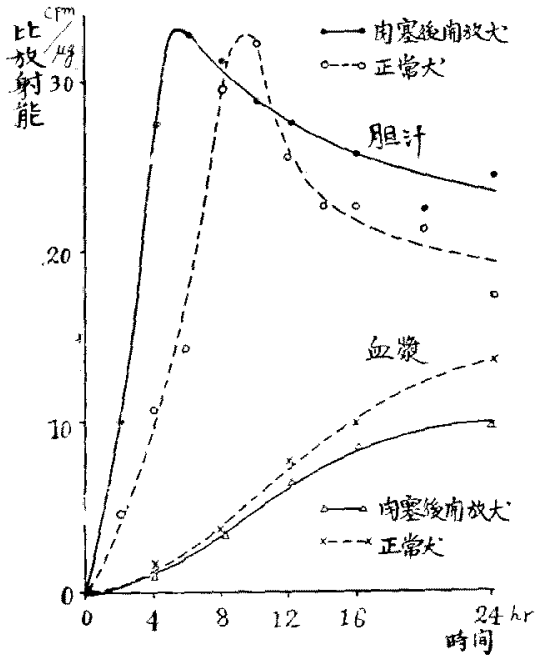

Eり迟み

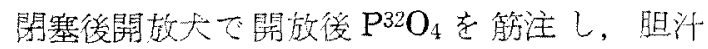

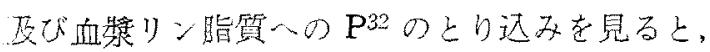
第 6 图の如く血嶈りン脂質の比放射能は極內て禹 るやかな嬶加を見，対照の正常犬上りもむしろ低 く疗つている。こ㞦に対し胆汁リン脂質の比放射 能は対照よりも速かに4 時間で最高になる。

閤塞後開放犬で開放 8 時間前に $\mathrm{P}^{32} \mathrm{O}_{4}$ を注射

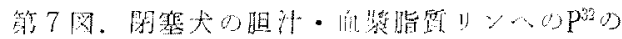

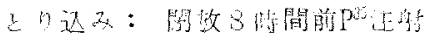

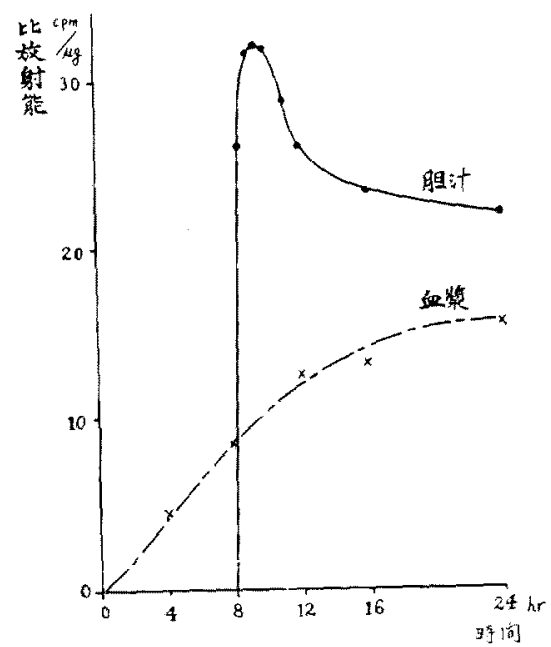

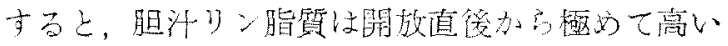
故射能方見られ，胆管閉害の状態一胆汁りン脂

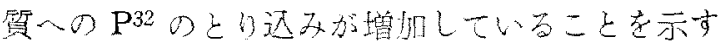
(䈏了园).

以上の成績老総括すると, 第8圂に示文ように $\mathrm{P}^{32} \mathrm{O}_{4}$ 筇注㣪 24 時間の間に胆汁に分记された脂 質りンの放身能妵，正常大に比し閉塞传開放大で

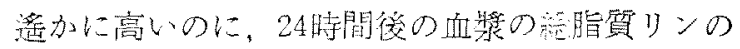
放射能はこの雨者の閒に活とんど差方ない。㞦

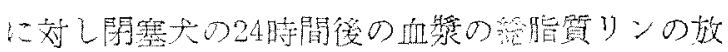
射能が，正常犬上り离く劣つている。

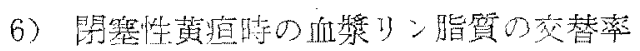

イマに $\mathrm{P}^{32} \mathrm{O}_{4} 3 \sim 5 \mathrm{mc}$ 筋注し24時間得に

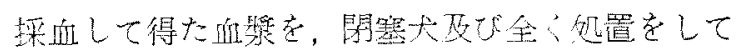
いない対琞犬は静注し，血漿リン脂質の比放射能 を時間的に見ると第9図の如き減衰示した。 れ办ら Zilversmit らの等式13に上つて艾替時間

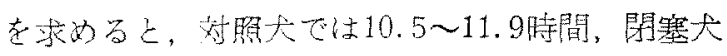

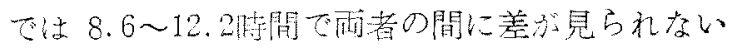
(第 6 表).

\section{IV 総括並びに考案}

胆汁リン脂筫量について古くより見られる報告

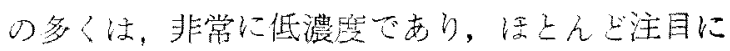




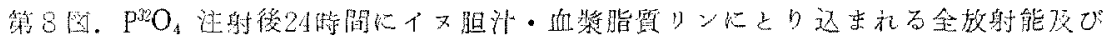

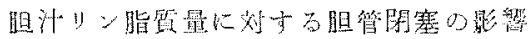
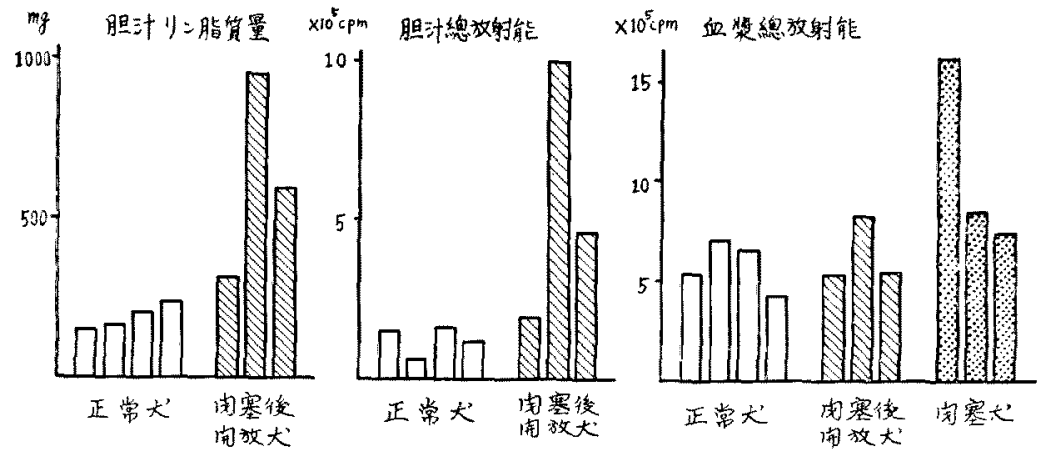

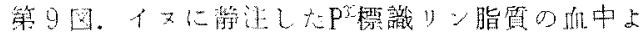
3) 9消车

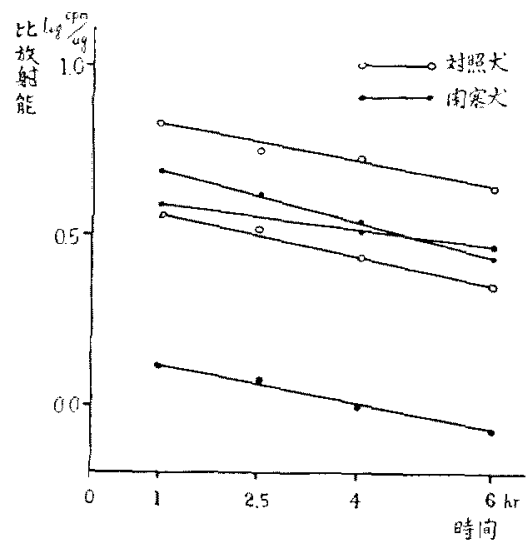

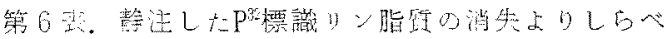

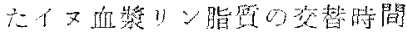

\begin{tabular}{|c|c|c|c|}
\hline & $\begin{array}{r}\text { リン脂筫り义 } \\
\mu \mathrm{g} / \mathrm{ml}\end{array}$ & $\begin{array}{c}\text { 交替時间 } \\
b r\end{array}$ \\
\hline \multirow{2}{*}{$\begin{array}{l}\text { 対 } \\
\text { 照 } \\
\text { 犬 }\end{array}$} & 1 & 78.3 & 10.5 \\
\hline & 2 & 945 & 11.9 \\
\hline \multirow{3}{*}{$\begin{array}{l}\text { 安 } \\
\text { 塞 } \\
\text { 犬 }\end{array}$} & 1 & 207.0 & 10.5 \\
\hline & 2 & 189.0 & 12.2 \\
\hline & 3 & 126.0 & 8.6 \\
\hline
\end{tabular}

值しない程度であると記載している334)14)15). 1952 年 Isaksson は胆计脂貸の定最法老改良して発表
した4)。すな方方，徒来 Hammarsten Roger

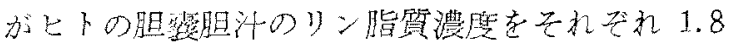
$\mathrm{mg} / \mathrm{ml}$ 及び $2.2 \mathrm{mg} / \mathrm{ml}$ 上報告しているのに齐 し，彼の改良法によ狄は，正常人の男及び女で胆 践胆汁のリン脂質濃度はそれぞれ11〜43平均27 $\mathrm{mg} / \mathrm{ml}$ 及び $15 \sim 53$ 平均 $34 \mathrm{mg} / \mathrm{ml}$ であると報告 している16)。胆汁の主成分である胆汁酸塩は水に 溶解して存在しており，この状態ではリン脂質の

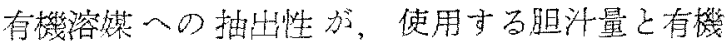
溶媒の量の割合によつて大きく影響される。著 者はZilversmit らの方泩12)に準じたが Dubin. Johnson氏症候群の男の患者で開腹時に得た胆霝 胆汁リン脂質濃度は，Isakssonの示したものに

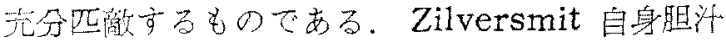
中の脂質りンと全りンを比較し，ての比がほ とんど1に近いことを兒ている。一方 Johnston

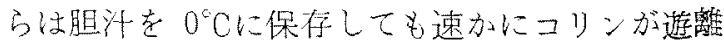
してくることを報告しているが17)，著者は胆汗を $37^{\circ} \mathrm{C}$ で 3 時間放置し脂暨りン並びに脂酸エステル

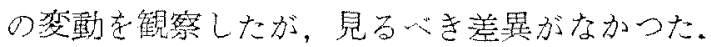
更に胆泩より抽出した脂望宾カラムクロマトグラ フィーで分析し，その脂質りンがレシチンの溶出 さ礼るべき分画に一致して溶出されていることる 部明すると同時に，in vivoで $\mathrm{P}^{32}$ にて標識した

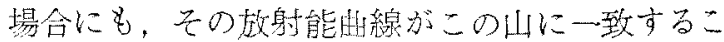
とも証明した。，以上著者の用いた胆汁リン脂質の 抽出並びに测定法は contamination のない老 


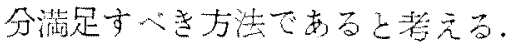

かっる力法て篦者名测定したイ又の胆汁リン脂 質濃度は，蓝来の $0.6 \sim 0.5 \mathrm{mg} / \mathrm{ml}$ という報告

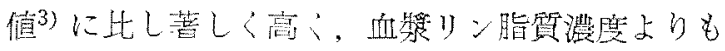
約 4 倍它高小，㹩つて 1 日の間に胆汁中に分泌さ

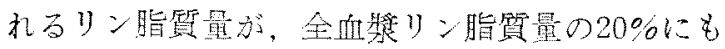
及ぶ事実は注目す心弆るる。

胆汁りン脂筫汃大部分レシチンから成ることは 字に古く加ら報告されている。 Johnstonらは Reineck 塩によるコリン定量によつて,䏣汁リン 脂質のコリン柯りンのモル比が症とんど1に近い

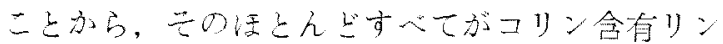
脂質であるこ上老報告した17)、都者の分析結果て はDNP化により測定せるエ夕ノールアミン・七 ファリンの量は, 胆汁中濃度 $0.15 \sim 0.55 \mu \mathrm{M} / \mathrm{ml}$,

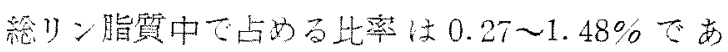
り，シリカร゙ルクロマブラフィーに上机壮3〜 6\%であつた。最近 Philips もシリカゲルクロー トグラフィーにより胆汁リン脂質を分析して同疗

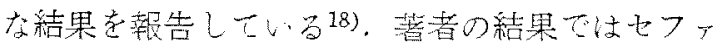
リン含量汶可成り变動が大きく，かつ胆整胆汁て 殊に高い值寺すこ上から考えて，胆计中の七つ

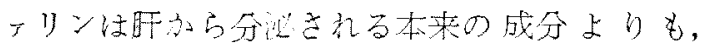
むしろ胆管や胆壁上定の洯脱に上つて生ずる二次

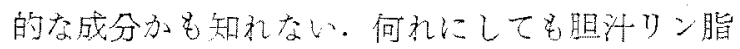
質の大部分はレシチンてある事奏に間違はない。 レシチンの山の传方に溶出するリン脂質量は多く の場合 $2 \sim 3 \%$ に過ぎ， Robins らの方法で DNP化によつて定量したスフィンゴミエりン量 も, $1 \%$ むむた。

in vivoて $\mathrm{P}^{32}$ によって朋のリン脂質要標裁 して分析すると, 各リン脂質がそれでれ異なつ た比放射能走示し，フォスファチジン酸やイノシ トールリン脂質の㐫るものが殊に高い交替率をも つことが報告されている19)。しかし著者は，胆汁 リン脂質中にこのような高い交替草を示卞少量部

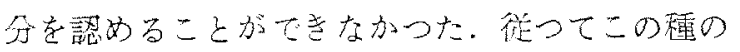
少量成分は, 全く旰細胞加方分熦されないもので あ亏う。
リン脂筫のほをんどがレシチンで占められると いつても，只のレシチンは種々の脂肪酸の組合せ を持つことが想像さ扎る。䀒办ら胆汗中にリン脂 貿を分泌するに際して、これら脂肪酸り種類に上 る分议の選択性が存在するかどうか蝴明かでな い.シリカダルクロマトグラフィーの溶出䏣線方 ら見ると，胆汁りン脂犋の不飽和度に関しての分 布状態は全肝リン指質と汪とんど夫差がない，又

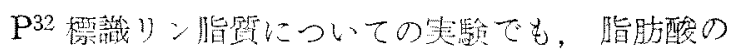

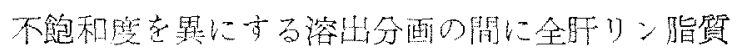

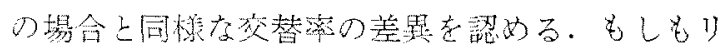

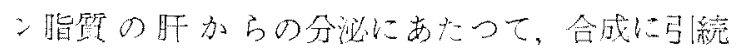
いておこる active な分泌過程老仅定すれば，胆 汁りン脂質の比教射能俚脂肪酧の種類によらず一 定となることが推定される。しかし著者の成績は 二机に否定的であり，䣋胞成分の照選択的流出と 考えられるが，脂酸の種類に上るリン脂筫分泌の 選択性の存否に閣して证，な扮今淩追求す心き問 題〔あるう。

血清リン脂筫はほとんよ゙すいて旰において合成。 され，旰にて処理される。㕛胆汁リン脂質も旰か ら直接分泌されることが明らかである。徒つて䦥 塞性黄疸時の高リン脂質血の成因としては，1） 䀒におけるリン脂質合成の增加，2)胆汁りン脂琶 の血中への逆流，3)旰又はその他の組織による血 等りン脂筫の掑取文は分解の減少によることが考 充狆る。

閉塞性黄迫患者の血清リン脂筫人のP32 のと

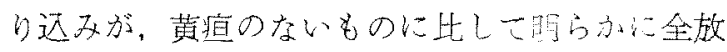

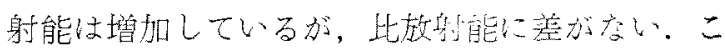
の事奏は畈におけるリン脂質企成の增加を柰す ものである、しかしながらその比放射能の減少が ないからといつて, Balfour の如く胆汁リン脂 質の血中人の证流や，旰に扔けるりン脂質処理

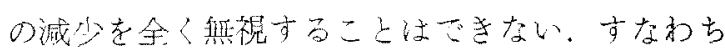

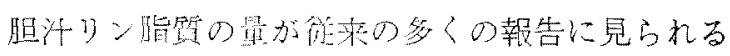
如く少量である古らば，そして及胆汁りン脂質の

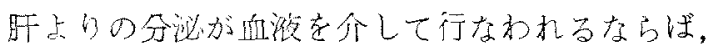
Balfour の如く胆汁りン眧筫の逆流を無視して 
もよい，しかし胆汁リン脂質の量は然視するには 余りにも大冒であり，全血浆りン脂質の20\%に及 ぶリン脂質が 1 日の間に胆汁中に分必されてい る。開塞後開放犬では胆汁のうつ滞が開放された ためとはいえ，実に全血獎りン脂質の50\%に相当 するリン脂筫が1日の閒に胆汁に分必される。

Popperは䀒胆汁リン脂質濃度は $0.1 \mathrm{mg} / \mathrm{ml}$ 超えず，胆道を通じてのりン脂䫓の分泌は血清り

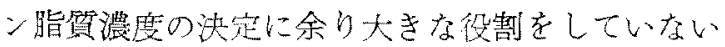

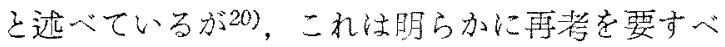
きだうう。

盟管閉塞及び正常の家雭で， $\mathrm{P}^{32} \mathrm{O}_{4}$ 筋注㣪の血 清りン脂質の比放射能は，胆管閉塞家雭の方が正 常よりを急激比上累した。これはイ邓用いての 考験でも同様であり，殊に䏣汁りン脂質の比放射 能が著明に高くなる初めの数時間に，血嶈リン脂 貿の比放射能が閉塞犬で正常犬に比して著明に上 昇することは，胆汁りン脂質の血中への逆流の存 在を筧わ放ものである。更に開塞後閏放犬の胆 汁リン脂質の此放射能が正常犬より速かに最高に 蒸し， 1 日間の胆汁リン脂質の全放射能も多い二

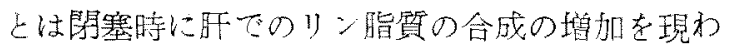
すが，同時に見られる血棌りン脂質の比放射能が 玨掌犬よりも低く，閉塞犬に比し著明に減少して いる事実注，胆管門塞時の高りン脂頯血の成因に 対し胆汁リン脂質の逆流が闑与している明白な証 挑だある。

灵後に $\mathrm{P}^{32}$ 標識りン䁆筫を静注し血獎りン脂質 の爬理を見ると，血中標識リン脂質の交替洔間は 対撜大と閉塞大との間に差異がみられない。すな わち閉塞性黄疸時の高りン脂質血に，血漿りン脂 覧の処理の減少が関与している可能性は一态否定 される。

\section{$\mathbf{V}$ 結 論}

1）胆汁りン脂頛濃度は，侻来の諸家の報告よ りも著明に高く，正常犬の旰胆汁では，レシチン

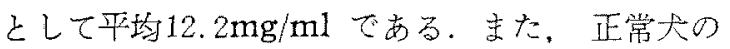
胆汁に分泌されるリン䁕質の1日量は全血嶈りン 脂買量の約 $20 \%$ に相当古る。

2) 盟汁リン脂質の成分は、注上んどすいてが レシチンであり，七ファリンはモル比で $1 \sim 6 \%$ ， スフィンゴミエリンはモル比で $1 \%$ 以下である。

3）胆汁リン脂側のシリカゲルクロマトグラフ
ィーにおいて、レシチンの山の中で諘められる䁕 肪酸の不飽和度並びに比放射能の溶出曲線は，全 旰リン脂質に認められるものと殆と同じである。

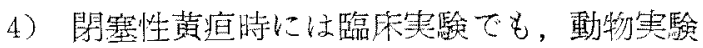
でも $\mathrm{P}^{32} \mathrm{O}_{4}$ 筋注後に血清又は血獎リン脂質にと り込まれる棇放射能は正常より增加し, 胆管閉塞 後 3 日目に開放せるイ又に少いては, 胆汁りン䁕 質の比放射能は正常大よりも速かに最高に達し。 旰のリン脂質合成が增加していることが証明され る.

5) $\mathrm{P}^{32} \mathrm{O}_{4}$ 筋注後24㭙間に胆汁リン脂質に出現 する総放射能は，胆管閏塞後 3 日目に開放したも のが正常よりも高いのに，血漿リン脂質にとり込 まれる放射能はこの両者の間に大差がない。

6）胆管閉塞大に静注した血獎 $\mathrm{P}^{32}$ 標識りン脂 質の交替㭙間は，対盟大と变らず，血獎りン脂質 の交替率は開塞性黄㾝時に減少していない。

7) 以上の成續加的閉塞性黄疸時の高りン脂質 血の成因に，胆汁りン脂質の血中への逆流が大き な役割在果すこと妾明らかにした。

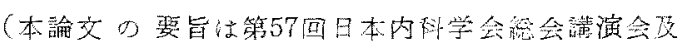
び第33回日本生化学会総会で発瑟し太。

\section{文献}

1) Isaksson: Acta Soc. Med. Upsaliensis, 59, $296(1953-54)$. - 2) Johnston et al: Arch.

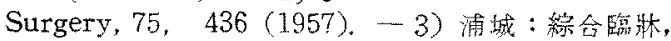
7,2255 (昭33). -4) Isaksson: Acta Soc. Med. Upsaliensis, 56, 177 (1952). - 5) Zilversmit et al: Arch. Biochem. and Biophys., 73, 224 (1958). -6) Balfour: Gastroent., 9, 686, (1947). - 7) Folch et al: J. Biol. Chem., 226, 497 (1957). - 8) Fiske and Subbarow: J. Biol. Chem., 66, 375, (1952). - 9) Axelrod et al: J. Biol. Chem., 204, 903 (1953). - 10) Robins et al: J. Biol. Chem., 220, $661(1956),-11) \mathrm{Ha}$ nahan et al: J. Biol. Chem., 228, 685 (1957). - 12) Witter et al: Arch. Biochem. and Biophys., $68,15(1957)$ - - 13) Zilversmit et al: J. Biol. Chem., 176, 209 (1948). - 14) Jones et al: Proc. Soc. Exp. Biol. and Med., 35, 535 (1937). - 15) Schaffner et al: Fed. Proc., 10, 369 (1951). - 16) Isaksson: Acta Soc. Med. Upsaliensis. 59, $277(1953-54) .-17)$ Johnston et al: J. Biol. Chern., 131, 425 (1939). - 18) Phillips: Biochem. Biophys. Acta, 41, 361(1960). - 19) Hokin et al: J. Biol. Chem., 233, 805 (1958). - 20) Popper et al: Liver: Structure and Function, McGrow-Hill Book Co., 34(1957). 